\title{
Self-Care of Patients with Diabetes Mellitus Cared for at an Emergency Service in Mexico ${ }^{1}$
}

\author{
Irasema Romero Baquedano² \\ Manoel Antônio dos Santos ${ }^{3}$ \\ Tatiane Aparecida Martins ${ }^{4}$ \\ Maria Lúcia Zanetti ${ }^{5}$
}

\begin{abstract}
This study examines the self-care ability of type 2 diabetes mellitus patients and relates it to sociodemographic and clinical variables. The study included 251 patients who were cared for by an emergency service in Mexico, in 2007. Data were obtained through structured interviews held at participants' households, through a form, a questionnaire and the Self-Care Ability Scale. Descriptive and correlation statistics were used for data analysis. The results show that $83(33.5 \%)$ individuals displayed good self-care ability and 168 (66.5\%) individuals displayed regular ability. A directly proportional correlation was found between self-care ability and schooling $(r=0.124$; $p<0.05)$, as well as a negative correlation for religion $(r s=-0.435 ; p<0.05)$ and duration of disease evolution $(r=-0.667 ; p<0.05)$. The conclusion is that most of the individuals with type 2 diabetes mellitus displayed regular ability for self-care. Self-care ability is related to multiple variables that should be taken into account by health professionals when suggesting educational programs.
\end{abstract}

Descriptors: Self Care; Diabetes Mellitus; Nursing; Health Services.

\footnotetext{
${ }^{1}$ Article extracted from Doctoral Dissertation "Fatores relacionados ao autocuidado de pessoas com diabetes tipo 2 no Serviço de Urgência do Hospital Regional Mérida, Yucatán, México", presented to Programa de Pós-graduação em Enfermagem Fundamental, Escola de Enfermagem de Ribeirão Preto, Universidade de São Paulo, WHO Collaborating Centre for Nursing Research Development, SP, Brazil.

2 RN, Ph.D. in Nursing, Escola de Enfermagem de Ribeirão Preto, Universidade de São Paulo, agreement with Facultad de Enfermería y Obstetrícia de Celaya, Universidad de Guanajuato, Celaya, Mexico. E-mail: irasemaromero@hotmail.com.

${ }^{3}$ Psychologist, Ph.D. in Psychology, Professor, Faculdade de Filosofia, Ciências e Letras de Ribeirão Preto, Universidade de São Paulo, SP, Brazil. E-mail: masantos@ffclrp.usp.br.

${ }^{4}$ Undergraduate Student at Nursing Diploma Program, Escola de Enfermagem de Ribeirão Preto, Universidade de São Paulo, WHO Collaborating Centre for Nursing Research Development, SP, Brazil. E-mail: tatiane.martins@usp.br.

${ }^{5}$ RN, Ph.D. in Nursing, Associate Professor, Escola de Enfermagem de Ribeirão Preto, Universidade de São Paulo, WHO Collaborating Centre for Nursing Research Development, SP, Brazil. E-mail: zanetti@eerp.usp.br.
}

Corresponding Author:

Maria Lúcia Zanetti

Universidade de São Paulo. Escola de Enfermagem de Ribeirão Preto.

Departamento de Enfermagem Geral e Especializada.

Av. Bandeirantes, 3900, Campus Universitário

Bairro Monte Alegre

CEP: 14040-902 Ribeirão Preto, SP, Brasil.

E-mail: zanetti@eerp.usp.br 


\title{
Autocuidado de pessoas com diabetes mellitus atendidas em serviço de urgência no México
}

Este estudo teve por objetivos determinar a capacidade de autocuidado de pessoas com diabetes mellitus tipo 2 e relacionar esse distúrbio com algumas variáveis sociodemográficas e clínicas. Participaram 251 pessoas que ingressaram em um hospital de urgência no México, em 2007. Os dados foram obtidos mediante entrevista domiciliar dirigida, utilizando-se de formulário, questionário e Escala de Capacidade de Autocuidado. Para a análise, utilizou-se estatística descritiva e correlacional. Os resultados mostraram que $83(33,5 \%)$ sujeitos apresentaram boa capacidade de autocuidado e $168(66,5 \%)$ capacidade regular. Obteve-se correlação diretamente proporcional entre capacidade de autocuidado e anos de estudo $(r=0,124 ; p<0,05)$ e negativa para religião ( $r s=-0,435$; $p<0,05)$ e tempo de evolução da doença $(r=-0,667 ; p<0,05)$. Conclui-se que a maioria das pessoas com diabetes mellitus tipo 2 apresentou capacidade de autocuidado regular. A capacidade de autocuidado está vinculada a múltiplas variáveis, que merecem atenção dos profissionais de saúde quando da proposição de programas de educação.

Descritores: Autocuidado; Diabetes Mellitus; Enfermagem; Serviços de Saúde.

\section{Autocuidado de personas con Diabetes Mellitus atendidas en un servicio de urgencia en México}

\begin{abstract}
Este estudio tuvo por objetivos determinar la capacidad de autocuidado de personas con diabetes mellitus tipo 2 y relacionar esa capacidad con algunas variables sociodemográficas y clínicas. Participaron 251 personas que ingresaron en un hospital de urgencia en México, en 2007. Los datos fueron obtenidos mediante entrevista domiciliar dirigida, utilizándose de formulario, cuestionario y Escala de Capacidad de Autocuidado. Para el análisis se utilizó estadística descriptiva y correlacional. Los resultados mostraron que $83(33,5 \%)$ sujetos presentaron buena capacidad de autocuidado y $168(66,5 \%)$ capacidad regular. Se obtuvo una correlación directamente proporcional entre capacidad de autocuidado y años de estudio $(r=0,124 ; p<0,05)$ y una correlación negativa con la religión ( $r s=-0,435$; $p<0,05)$ y tiempo de evolución de la enfermedad $(r=-0,667 ; p<0,05)$. Se concluye que la mayoría de las personas con diabetes mellitus tipo 2 presentó una capacidad de autocuidado regular. La capacidad de autocuidado está vinculada a múltiples variables, que merecen atención de los profesionales de salud cuando se realiza la proposición de programas de educación.
\end{abstract}

Descriptores: Autocuidado; Diabetes Mellitus; Enfermería; Servicios de Salud.

\section{Introduction}

There are different definitions of self-care in specific cultural and social contexts( ${ }^{(1)}$. In the Americas, selfcare refers to actions people adopt in favor of their own health without formal medical supervision. It is defined as practices carried out by people and family members through which positive health behaviors are promoted to prevent diseases and treat symptoms ${ }^{(1)}$.

Historically, nursing is a discipline that seeks to educate people in self-care ${ }^{(1)}$. Self-care is defined as a regulating function, which individuals deliberately use to maintain vital requirements, for development and integral functioning(2).

The ability to perform self-care is developed over life through a spontaneous learning process, given the maturation of intellectual curiosity, with guidance and supervision and experience with self-care measures ${ }^{(3)}$.

Self-care is also considered part of people's life style, which is understood as a standards of conduct 
that reflect on the way individuals interact in the social milieu(3). The concept of lifestyle is broad and involves standards that emerge from the selection of options available to people according to their social and economic circumstances, and the facility with which they can choose other alternatives. Hence, the choice of a healthy lifestyle implies concrete self-care actions such as self-medication, self-treatment, social support and care taken in situations of disease in the individual's environment ${ }^{(3)}$.

The World Health Organization recommends promoting self-care education to prevent and treat chronic diseases ${ }^{(1)}$. Self-care education for people with chronic health problems should promote the development of self-care skills so that individuals share and assume responsibility for their own health and learn to live better with the disease, change or keep healthy habits, and promote self-reliance so they feel better regardless of the severity of the disease.

Self-care is an efficacious strategy to reduce the costs of health care, reduce the number of hospitalizations and emergency consultations, promote the rational use of medication and improve the relationship between health professionals and patients ${ }^{(1)}$.

In this context, self-care in health is defined as measures each person individually takes to protect his/ her physical, mental and social well-being. Self-care is based on the belief that human beings are capable of caring for their health and includes a series of actions to maintain physical and mental health, prevent diseases, satisfy physical and psychological needs, seek medical help or to self-medicate ${ }^{(1)}$.

When one considers that individuals with diabetes mellitus present a chronic condition that requires permanent care to maintain quality of life and metabolic control, one perceives the need to develop self-care skills to manage the disease. Especially for people with type 2 diabetes mellitus whose prevalence is associated with lifestyle, introducing changes in daily habits may be an effective strategy to prevent the disease ${ }^{(4)}$.

The role of multiprofessional health teams is to help individuals with diabetes to develop self-care skills to manage the disease in order to keep appropriate metabolic control, aiming to prevent or delay diabetesrelated chronic complications(5). The presence of a professional is particularly important when a person has difficulty taking responsibility for her/his self-care.

From this perspective, professionals need to know the variables related to self-care to provide effective care. Studies have addressed these issues, investigating variables related to access to information and knowledge, satisfaction with health services, family support, among other relevant psychosocial factors ${ }^{(5-9)}$.

Therefore, this study focuses on variables related to the self-care ability of people cared for in an emergency service of a general hospital to support the restructuring process of care provided to the population with diabetes in Mexico in the context of the Integrated Health Care Model (MIDAS)(10), an integral care community model oriented to the health needs of the population. Commitment linking professional care to the individual's self-care ability is assumed(10).

Identifying the variables related to self-care allows the identification of potential barriers for treatment adherence of people with type 2 diabetes mellitus and also the proposal of educational strategies to strengthen self-care in the studied population.

This study aims to determine the self-care ability of people with type 2 diabetes mellitus and relate this ability to gender, age, schooling, religion, duration of disease, and participation in support groups.

\section{Material and Method}

This cross-sectional and descriptive study was carried out in the emergency service of the Regional Hospital Mérida, Institute of Social Welfare and Services for State Workers (ISSSTE), Mérida, Yucatán, Mexico, from January to December 2007.

A convenience sample was used. Inclusion criteria were: people with diagnosis of type 2 diabetes mellitus, both genders, age between 30 and 80 years of age, residents of Mérida, Mexico, who were cared for by the emergency service of the previously mentioned hospital during the 12-month period defined by the study and voluntarily consented to participate in the study. Exclusion criteria were: people with type 2 diabetes mellitus who, after three consecutive visits, were not found at their households, moved to another address or died during the study period.

Of the 382 people with type 2 diabetes admitted into the service, 131 did not meet the inclusion criteria. The sample was composed of 251 people with type 2 diabetes mellitus who met the eligibility criteria.

\section{Data collection instruments}

The following were used to collect data: one registration form to obtain the list of patients (hospitalization day, patient's name and number of file, address and motive of hospitalization); one questionnaire 
with closed questions addressing socio-demographic and clinical variables, developed by the researcher based on a previous study ${ }^{(9)}$ (gender, age, schooling, marital status, occupation, religion and time since the disease clinical diagnosis); and one scale to measure self-care ability $^{(11)}$.

The Self-Care Ability Scale is an instrument developed and validated in Mexico(11). It is a Likert scale with 25 items that evaluate universal self-care requirements, of development and diversion of health, with a satisfactory level of reliability (Crombach's alpha $=0.86$ ). To evaluate self-care ability, a three-point score was attributed to the items "always", two to "frequently", one to "sometimes", and zero to "never". At the end, scores obtained in all the items were computed, which was compared with the proposed indicators: very good (57-75), good (38-56), regular (19-37), and poor $(0-18)$. The maximum possible score is 75 points.

\section{Procedure}

First, the medical files of the type 2 diabetes mellitus patients cared for in the regional Hospital of Mérida in the period determined by the study were reviewed. Then, the patients' medical files were found and data concerning date of hospitalization, name, file number, address and motive of hospitalization were recorded in the forms. With the respective addresses, patients and family members were visited at home for the purpose of clarification concerning the study's objectives. If they consented to participate in the study, a free and informed consent form was signed.

Socio-demographic and clinical data were obtained through the individual application of the questionnaire by the researcher at the participants' houses in 2007. The Self-care Ability Scale was applied after sociodemographic and clinical data were collected. The application of the instruments took an average of 30 minutes and was held at the participants' home in a private room.

To organize and analyze data through descriptive statistics, the statistical program SPSS version 12.0 was used. For the correlative descriptive statistics Pearson's $r$ was used to establish the relationship between proportion or interval variables and Spearman's correlation for the ordinal variables with the level of significance at $\mathrm{p}<0.05$.

The study complied with the standards required by the Helsinki Declaration and approved by the Committee on Bioethics at the College of Nursing and Obstetrics at Celaya, Mexico.

\section{Results}

Table 1 shows the characterization of the individuals' socio-demographic and clinical variables.

Table 1 - Distribution of people with type 2 diabetes cared for in an emergency service at the regional Hospital de Mérida according to gender, age group, schooling, marital status, occupation, religion, and duration of the disease evolution - Mérida, Yucatán, Mexico - 2007

\begin{tabular}{|c|c|c|c|}
\hline Variables & Categories & $\mathbf{N}$ & $\%$ \\
\hline \multirow[t]{2}{*}{ Gender } & Female & 130 & 51.8 \\
\hline & Male & 121 & 48.2 \\
\hline \multirow[t]{5}{*}{ Age group (years) } & $30-39$ & 8 & 3.2 \\
\hline & $40-49$ & 22 & 8.8 \\
\hline & $50-59$ & 61 & 24.3 \\
\hline & $60-69$ & 74 & 29.5 \\
\hline & $70-80$ & 86 & 34.2 \\
\hline \multirow[t]{4}{*}{ Schooling (years) } & $1-6$ & 94 & 37.5 \\
\hline & $7-9$ & 62 & 24.7 \\
\hline & $10-12$ & 59 & 23.5 \\
\hline & 13 or more & 36 & 14.3 \\
\hline \multirow[t]{4}{*}{ Marital Status } & Married & 205 & 81.7 \\
\hline & Widowed & 26 & 10.3 \\
\hline & Divorced & 15 & 6.0 \\
\hline & Single & 5 & 2.0 \\
\hline \multirow[t]{5}{*}{ Occupation } & House wife & 70 & 27.9 \\
\hline & Pensioner & 64 & 25.5 \\
\hline & Retired & 59 & 23.5 \\
\hline & Employed & 40 & 15.9 \\
\hline & Unemployed & 18 & 7.2 \\
\hline \multirow[t]{6}{*}{ Religion } & Catholic & 165 & 65.7 \\
\hline & Christians & 44 & 17.5 \\
\hline & Jehovah's Witnesses & 19 & 7.6 \\
\hline & Mormons & 11 & 4.4 \\
\hline & Atheist & 10 & 4.0 \\
\hline & Buddhist & 2 & 0.8 \\
\hline \multirow{3}{*}{$\begin{array}{l}\text { Time since the disease } \\
\text { clinical diagnosis (years) }\end{array}$} & $0-10$ & 61 & 24.3 \\
\hline & $11-20$ & 84 & 33.5 \\
\hline & 21 or more & 106 & 42.2 \\
\hline Total & & 251 & 100 \\
\hline
\end{tabular}

When self-care abilities of people with type 2 diabetes were analyzed, the minimum score 25 and the maximum 43 were found, average of 35.72 \pm 3.69 .

According to the proposal of classification of the Self-Care Ability Scale, the answers were grouped and categorized as: very good, good, regular and poor. The data obtained in relation to self-care ability (Table 2) showed that 83 (33.5\%) people with type 2 diabetes presented good self-care ability and 168 (66.5\%) regular ability. 
Table 2 - Distribution of people with type 2 diabetes mellitus cared for in the emergency care of the regional Hospital de Mérida according to categories proposed by the self-care ability instrument - Mérida, Yucatán México - 2007 Mérida, Yucatán, 2007

\begin{tabular}{llcc}
\hline Variable & \multicolumn{1}{c}{ Categories } & n & $\%$ \\
\hline Self-care ability & Very good & - & - \\
& Good & 84 & 33.5 \\
& Regular & 167 & 66.5 \\
& Poor & - & - \\
Total & & 251 & 100 \\
\hline
\end{tabular}

In relation to self-care ability related to gender (Table 3), we observed that 47 (18.7\%) women presented good self-care ability and $83(33.1 \%)$ regular. In relation to men, $37(14.7 \%)$ presented good self-care ability and $84(33.5 \%)$ regular.

Table 3 - Distribution of people with type 2 diabetes mellitus cared for in the emergency care service of the regional Hospital de Mérida according to self-care ability related to gender. Mérida, Yucatán, Mexico, 2007

\begin{tabular}{|c|c|c|c|c|c|c|}
\hline \multirow{3}{*}{ Gender } & \multicolumn{4}{|c|}{ Self-care ability } & \multirow{2}{*}{\multicolumn{2}{|c|}{ Total }} \\
\hline & \multicolumn{2}{|c|}{ Good } & \multicolumn{2}{|c|}{ Regular } & & \\
\hline & $\mathbf{n}$ & $\%$ & $\mathbf{n}$ & $\%$ & $\mathbf{n}$ & $\%$ \\
\hline Female & 47 & 18.7 & 83 & 33.1 & 130 & 51.8 \\
\hline Male & 37 & 14.7 & 84 & 33.5 & 121 & 48.2 \\
\hline Total & 84 & 33.4 & 167 & 66.6 & 251 & 100 \\
\hline
\end{tabular}

Concerning self-care ability in relation to age group (Table 4) the following groups displayed good self-care ability: $26(10.3 \%)$ individuals between 70 and 80 years of age, $25(10.0 \%)$ between 50 and 59 years of age, $22(8.8 \%)$ between 60 and 69 years of age, $10(4.0 \%)$ between 40 and 49 years of age, and one (0.4\%) between 30 and 39 years of age.

In relation to regular self-care ability: 60 (23.9\%) individuals between 70 and 80 years old, 52 (20.7\%) between 60 and 69 years of age, 36 (14.3\%) between 50 and 59 years of age, 12 (4.8\%) between 40 and 49, and seven (2.8\%) individuals between 30 and 39 years of age displayed regular self-care ability (Table 4).
Table 4 - Distribution of people with type 2 diabetes mellitus cared for in the emergency care of the regional Hospital de Mérida according to self-care ability related to age group - Mérida, Yucatán, Mexico, 2007

\begin{tabular}{|c|c|c|c|c|c|c|}
\hline \multirow{3}{*}{ Age group } & \multicolumn{4}{|c|}{ Self-care ability } & \multirow{2}{*}{\multicolumn{2}{|c|}{ Total }} \\
\hline & \multicolumn{2}{|c|}{ Good } & \multicolumn{2}{|c|}{ Regular } & & \\
\hline & $\mathbf{n}$ & $\%$ & $\mathbf{n}$ & $\%$ & $\mathbf{n}$ & $\%$ \\
\hline $30-39$ years & 1 & 0.4 & 7 & 2.8 & 8 & 3.2 \\
\hline $40-49$ years & 10 & 4.0 & 12 & 4.8 & 22 & 8.8 \\
\hline $50-59$ years & 25 & 10.0 & 36 & 14.3 & 61 & 24.3 \\
\hline $60-69$ years & 22 & 8.8 & 52 & 20.7 & 74 & 29.5 \\
\hline $70-80$ years & 26 & 10.3 & 60 & 23.9 & 86 & 34.2 \\
\hline Total & 84 & 33.5 & 167 & 66.5 & 251 & 100 \\
\hline
\end{tabular}

In relation to self-care ability related to schooling (Table 5), of the 94 (37.5\%) individuals who completed one to six years of schooling (primary school in Mexico): 29 (11.5\%) had good self-care ability and 65 (26.0\%) had regular self-care ability. Of the $62(24.7 \%)$ individuals who completed from seven to nine years of schooling (secondary school): 17 (6.8\%) had good ability to self-care and $45(17.9 \%)$ regular ability. Of the $59(23.5 \%)$ people who completed from 10 to 12 years of schooling: 22 (8.8\%) showed good self-care ability and $37(14.7 \%)$ regular ability. Of the $36(14.3 \%)$ people who had a bachelor's degree (13 or more years of schooling), $16(6.4 \%)$ had good self-care ability and $20(7.9 \%)$ had regular self-care ability.

Table 5 - Distribution of people with type 2 diabetes mellitus cared for in the emergency care of the regional Hospital de Mérida according to self-care ability related to schooling. Mérida, Yucatán, Mexico, 2007

\begin{tabular}{|c|c|c|c|c|c|c|}
\hline \multirow{3}{*}{$\begin{array}{l}\text { Years of } \\
\text { schooling }\end{array}$} & \multicolumn{4}{|c|}{ Self-care ability } & \multirow{2}{*}{\multicolumn{2}{|c|}{ Total }} \\
\hline & \multicolumn{2}{|c|}{ Good } & \multicolumn{2}{|c|}{ Regular } & & \\
\hline & $\mathbf{n}$ & $\%$ & $\mathbf{n}$ & $\%$ & $\mathbf{n}$ & $\%$ \\
\hline $1-6$ years & 29 & 11.5 & 65 & 26.0 & 94 & 37.5 \\
\hline $7-9$ years & 17 & 6.8 & 45 & 17.9 & 62 & 24.7 \\
\hline $10-12$ years & 22 & 8.8 & 37 & 14.7 & 59 & 23.5 \\
\hline 13 or more years & 16 & 6.4 & 20 & 7.9 & 36 & 14.3 \\
\hline Total & 84 & 33.5 & 167 & 66.5 & 251 & 100 \\
\hline
\end{tabular}

Considering self-care ability related to reported religion, of the $84(33.5 \%)$ people who presented good 
self-care ability: 80 (31.9\%) were Catholic, three (1.2\%) were Christians, and one $(0.4 \%)$ was Mormon. Of the $167(66.5 \%)$ individuals with regular self-care ability: 85 (33.8\%) were Catholic, 41 (16.3\%) Christians, 19 (7.6\%) Jehovah's witnesses, 10 (4.0\%) were Mormons, two $(0.8 \%)$ were Buddhists, and 10 (4.0\%) were atheists.

In regard to self-care ability related to time since the disease clinical diagnosis, of the $84(33.5 \%)$ individuals who presented good self-care ability: 44 (17.6\%) had the disease from one to 10 years, 36 (14.4\%) from 11 to 20 years, and four (1.5\%) 21 years or more. Of the $167(66.5 \%)$ individuals who presented regular self-care ability: $17(6.7 \%)$ had the disease from one to 10 years, $48(19.1 \%)$ from 11 to 20 years, and 102 (40.7\%) for 21 year of more.

When analyzing the correlation between self-care ability and years of schooling ( $r=0.124 ; p<0.05)$, a directly proportional correlation was found between these two variables, that is, the higher the schooling level, the higher the individuals' self-care ability.

Considering the correlation between self-care ability and religion, a negative correlation was found $\left(r_{s}=-\right.$ $0.435 ; p<0.05)$, that is, the lower the belief expressed in religion, the higher the self-care ability.

Finally, an inversely proportional correlation was found between time since the disease clinical diagnosis and higher self-care ability in the studied individuals $(r=-0.667 ; p<0.05)$.

\section{Discussion}

Currently, there are recommendations to develop self-care abilities among people with diabetes to control the disease ${ }^{(10)}$. For that, individuals with diabetes mellitus need to actively participate in the monitoring of the disease: food choice, numbers of meals, quality and quantity of food, regularity of physical activity, selfmonitoring of capillary glucose, feet examination, use of correct medication doses and schedule, periodical medical consultations, knowledge of signs and symptoms of hyperglycemia, among others.

The average score obtained when analyzing the selfcare ability of people with type 2 diabetes mellitus was $35.72 \pm 3.69$. A total of $33 \%$ of the individuals presented good self-care ability and $67 \%$ regular self-care ability in the Self-Care Ability Scale. None presented very good or poor self-care ability.

When considering the score obtained by the individuals in this study in relation to self-care ability, one needs to take into account the individuals' average age, older than 65 years. People in this age range have self-care requirements related to the phase of the life cycle itself as well as co-morbidities, demanding support and close follow-up of family members ${ }^{(12)}$.

The score obtained in relation to self-care ability lead to the reflection that people with type 2 diabetes mellitus might have low motivation for self-care and/or limitations given impairment related to co-morbidities and chronic conditions. From this perspective, the literature indicates that when a person with diabetes presents some impairment and/or limitation, the presence of a professional is essential to motivate and help the individual to develop self-care abilities ${ }^{(8)}$.

Diabetes mellitus is considered a highly complex disease and most people with type 2 diabetes are diagnosed in the adult phase, which imposes a challenge to health educators given the peculiarities of the learning process of adult individuals to ensure effective interventions that really favor the incorporation of selfcare in the disease management.

The diagnosis of a chronic disease such as type 2 diabetes mellitus implies adopting self-care behavior for the entire life, including changes in lifestyle compatible with their own concept of quality of life. Given these circumstances, abandoning part or the entire prescribed treatment is not uncommon ${ }^{(13)}$. Because this is a disease that requires permanent care, adherence to treatment might be low, resulting in poor metabolic control. A study revealed that only a fraction of people with type 2 diabetes regularly realizes follow-up in health institutions and only $25 \%$ to $40 \%$ achieve the desired metabolic control ${ }^{(10)}$.

Knowledge is another critical variable that can explain the score obtained by the studied individuals related to self-care abilities. One study addressing the importance of having knowledge about self-care in diabetes mellitus showed that a low level of information about the disease and its etiology hinders the learning process, harms prevention and early diagnosis and increases the probability of other complications ${ }^{(7)}$.

In relation to self-care ability according to age, one has to consider that age is an important factor in the perception of environmental barriers for treatment adherence. The older the individual, the higher his/ her perception of environmental barriers. On the other hand, the youngest people are those who least perceive environmental barriers ${ }^{(14)}$.

The absolute increase of the Mexican population is in itself a challenge for the health system. The change in the age pyramid shows that the Mexican population 
is aging. The health problems of the adult population, between 45 and 64 years of age and the older population, show that the demand is growing with repercussions on the economic and organizational spheres ${ }^{(10)}$. Mexico is going through a demographic and epidemiological transition. Health professionals need to rethink effective strategies to care for older individuals, considering the specificities of this phase of the life cycle $^{(10)}$

Age is a factor that interferes in health needs during life cycle development. An adult individual has values, beliefs and habits already formed when s/he receives the diagnosis of type 2 diabetes mellitus. The onset of diabetes at this stage of life might be accompanied by resistance to change, which might explain, in part, data obtained in this study(2). Hence, age is a variable important to be taken into account when evaluating selfcare ability and when providing education in diabetes for managing the disease. Consequently, it is a relevant variable that can influence treatment-adherence.

Another aspect to consider is the proportion of Mexican individuals who develop type 2 diabetes before 40 years of age ${ }^{(15)}$. Considering that these individuals are exposed to the effects of hyperglycemia for a prolonged period of time and are thereby at a higher risk to develop chronic diseases, the impact of such diseases on the Mexican Health System might become unsustainable. It is necessary that Mexican policies guiding care directed to individuals with diabetes be urgently consolidated.

In relation to self-care ability related to years of schooling, individuals with higher levels of schooling showed good self-care ability, thus, that self-care is influenced by individuals' schooling. It is expected that the higher the years of schooling the better the individuals' self-care abilities ${ }^{(1)}$. Hence, people who received more years of formal education tend to present more knowledge and ability for self-care and also better ability to relate with the health team ${ }^{(5)}$.

Given the disease's complexity, schooling years is a variable that should be considered in planning educational programs for diabetes designed to develop self-care abilities. From this perspective, health professionals should consider this variable and seek diversified and innovative teaching strategies capable of mobilizing people with diabetes to self-care.

The analysis of self-care in relation to religious beliefs should account for the fact that people might place the responsibility for self-care on a superior being. A person may not value the acquisition of knowledge, skills and motivation to self-care when s/he delegates this responsibility. Hence, the development of self-care abilities becomes limited, since it is considered an issue exogenous to the individual. In this case, health professionals should seek strategies designed to enable individuals to assume the responsibility for their own self-care.

Because type 2 diabetes mellitus is a chronic disease, it demands patients to maintain self-care behavior for their entire lives. This condition is one of the factors that determine treatment-adherence. When the self-care ability is undermined, one of the consequences might be unsatisfactory metabolic control. One study showed that only a small portion of people with diabetes regularly seeks health services and only $25 \%$ to $40 \%$ of these have satisfactory metabolic control(16).

From this perspective, it is the role of the multiprofessional team to strengthen the ability of patients with type 2 diabetes mellitus through the implementation of innovating educational strategies capable of enabling the acquisition of knowledge and development of attitudes to manage the treatment and thereby achieving a good metabolic control(17).

\section{Conclusion}

The results obtained in this study allowed determining that most of people with type 2 diabetes mellitus displayed regular self-care ability (66.5\%), and this is related to socio-demographic and clinical variables.

Self-care ability related to gender indicated that the studied women displayed better self-care abilities compared to men. Better self-care abilities were also found among individuals between 70 and 80 years of age. Individuals with six years of schooling presented better self-care abilities as did those who reported being Catholic. In relation to duration of disease, the results indicated that the longer a person has diabetes, the worse is her/his self-care ability.

These findings indicate that the self-care ability of people with type 2 diabetes mellitus is linked to multiple factors that deserve attention from health professions when proposing educational programs. This study's findings improve the understanding of social and cultural factors as an important dimension of self-care.

The scarcity of studies addressing the ability of individuals with type 2 diabetes mellitus to self-care is a limitation that hinders our understanding of the results obtained in this study for the Mexican context. Further studies addressing other variables that might be related to self-care abilities are needed to enable future comparisons. 


\section{Referências}

1. Organización Panamericana de Salud. Fortalecimiento del autocuidado como estrategia de la Atención Primaria en Salud: la contribución de las instituciones de salud en América Latina. Chile (Santiago): Organización Panamericana de la Salud; 2006.

2. Orem DE. Nursing: concepts of practice. 6th ed. St Louis: Mosby; 2001.

3. Kickbusch I. Self-care in health promotion. Soc Sc Med. $1989 ; 29(2): 125-30$.

4. Tuomilehto J, Lindström J, Eriksson JG, Valle TT, Hämäläinen $\mathrm{H}$, Ilanne-Parikka $\mathrm{P}$, et al. Prevention of type 2 diabetes mellitus by changes in lifestyle among subjects with impaired glucose tolerance. N Engl J Med 2001;344(18):1343-50.

5. Otero LM, Zanetti ML, Souza CRT. Sociodemographic and clinical characteristics of a diabetic population at a primary level health care center. Rev. Latino-Am. Enfermagem. 2007; 15(no. spe):768-73.

6. Otero LM, Zanetti ML, Ogrizio MD. Knowledge of diabetic patients about their disease before and after implementing a diabetes education program. Rev. Latino-Am. Enfermagem. 2008;16(2):231-7.

7. Pace $A E$, Ochoa-Vigo K,Caliri MHL, Fernandes APM. O conhecimento sobre diabetes mellitus no processo de autocuidado. Rev. Latino-Am. Enfermagem. 2006;14(5):728-34.

8. Péres DS, Santos MA, Zanetti ML, Ferronato AA. Dificuldades dos pacientes diabéticos para o controle da doença: sentimentos e comportamentos. Rev. Latino-Am. Enfermagem. 2007; 15(6): 1105-12.
9. Zanetti ML, Otero LM, Biaggi MV, Santos MA, Péres DS, Guimarães FPM. Satisfaction of diabetes patients under follow-up in a diabetes education program. Rev. Latino-Am. Enfermagem. 2007; 15(4):583-9.

10. Secretaria de Salud (MX). Programa Nacional de Salud 20012006: La democratización de la salud en México. México (DF): Secretaría de Salud; 2001.

11. Díaz GR, Jordán JML, Vera RAM, Ruiz PL, Olalde GE. Escala de Capacidad de Autocuidado. 2004 junio. Celaya: Facultad de Enfermería y Obstetricia de Celaya, Universidad de Guanajuato; 2004.

12. Zanetti ML, Biaggi MV, Santos MA, Péres DS, Teixeira CRS. $\mathrm{O}$ cuidado à pessoa diabética e as repercussões na família. Rev Bras Enferm. 2008; 61(2):186-92.

13. Leite SN, Vasconcellos MPC. Adesão à terapêutica medicamentosa: elementos para a discussão de conceitos e pressupostos adotados na literatura. Ciênc Saúde Colet. 2003;8(3):775-82.

14. Martinez AO, Moreno MMG. Barreras ambientales para el apego al tratamiento en pacientes con diabetes tipo 2. Desarrollo Científico Enferm 2006;14(6):196-201.

15. Secretaría de Salud (MX). Programa de Acción: diabetes mellitus. México: Secretaría de Salud; 2001 noviembre 22.

16. Clement S. Diabetes self-management education. Diabetes Care. $1995 ; 18(8): 1204-14$.

17. Rodrigues FFL, Zanetti ML, Santos MA, Martins TA, Sousa VD, Teixeira CRS. Conhecimento e atitudes: componentes para a educação em diabetes. Rev. Latino-Am. Enfermagem. 2009;17(4):468-73.

Received: Ago. $4^{\text {th }} 2009$

Accepted: May. $3^{\text {rd }} 2010$ 